\title{
A Review of MOOCs in the Arab World
}

\author{
Marwan H. Sallam ${ }^{1,2}$ \\ ${ }^{1}$ Institute of Educational Technology, Zhejiang University, Hangzhou, China \\ ${ }^{2}$ Faculty of Education, Ibb University, Ibb, Yemen \\ Email: sallam@zju.edu.cn
}

How to cite this paper: Sallam, M. H (2017). A Review of MOOCs in the Arab World. Creative Education, 8, 564-573. https://doi.org/10.4236/ce.2017.84044

Received: February 16, 2017

Accepted: April 21, 2017

Published: April 27, 2017

Copyright $\odot 2017$ by author and Scientific Research Publishing Inc. This work is licensed under the Creative Commons Attribution International License (CC BY 4.0).

http://creativecommons.org/licenses/by/4.0/

\begin{abstract}
This review paper reports the main Arab initiatives on the Open Online Education followed by Massive Open Online Courses (MOOCs) in the Arab world. This paper provides a detailed description on the Rwaq and Edraak Platforms. The findings show that such platforms were not proposed inside the Arab universities, also indicated that the participation of Arab universities is still very weak in the movement of Massive Open Online Courses (MOOCs).
\end{abstract}

\section{Keywords}

MOOCs, Arab MOOCs, Open Online Education, Rwaq, Edraak

\section{Introduction}

In recent decades, the world has witnessed rapid development in the area of information and communication technology. These developments have a significant impact on many human life aspects. Education is one of the most important aspects of human life. Due to the information revolution, education is no longer confined to classrooms, schools, and universities. It has become, on the other hand, open to anyone having internet access. They can have their education online anywhere and anytime. To sum up, this kind of education is internationally known as Open Online Learning.

Open Online Learning can be identified as an approach offering different courses on different educational fields via the web. These courses are now termed as Massive Open Online Courses (MOOCs). These Massive Open Online Courses (MOOCs) are online courses designed with the intent for providing unlimited participation openly for anyone via the internet (Evans \& Schenarts, 2016). In addition to the traditional course materials such as video lectures, readings, and problem sets, many MOOCs provide comments and interactive user forums to support community interactions between students, teachers and 
teaching assistants (Conole, 2015). MOOCs were first established in 2008 by Dave Cormier and Brian Alexander (Jansen, Schuwer, Teixeira, \& Aydin, 2015), and emerged as a popular mode of learning in 2012 (Zhang, Wang, \& Chen, 2015).

In developed countries, Massive Open Online Courses (MOOCs) are successful and dramatically increase every year. However, the situation is different around the world and especially in Arab countries. MOOCs strongly depend on the digital infrastructure, PC, tablet, smartphone, and internet penetration and connection costs, which hugely vary from one Arab country to another. The situation seemingly appears to be advantageous in the Arab Gulf countries like Bahrain, the UAE and Qatar, where the proportion of the use of the internet among the population is more than 90\% (Middle East Internet Statistics, 2015) and least favorable in countries such as Somalia and the Comoros, where the proportion of internet use among the population is less than 10\% (Africa Internet Users, 2015).

The paper is organized into four sections, the first section is the introduction, the second section describes three Arab initiatives in the field of open online education in Arab countries before MOOCs, the third section presents Rwaq and Edraak platforms as the main MOOCs platforms in the Arab countries. The conclusion and recommendations are reported in section four.

\section{Open Online Education in Arab Countries before MO0Cs}

The increasing use of internet in the Arab countries has contributed to the appearance of some initiatives concerning the deployment of open online education. Initially, there were individual initiatives established to record videos explaining specific lessons and uploading them on the YouTube channel. With the passage of time, they developed this movement to become more organizational. In this part of paper, three different types of these free open online education initiatives that started before Arab MOOCs are reviewed. Aldarayn Academy for Free Online Education was established in 2011. In the same year (August 2011) the Arab ELearning Academy was established. One year later, Tahrir Academy was founded.

\subsection{Aldarayn Academy}

Aldarayn Academy, a charity and non-profit organization, was founded in 2011 (Aldarayn Academy for Free Online Education, 2014). It is the first open Arab academy established to provide "free" open online education for Arab speakers. Aldarayn Academy provides online training for all. It is aimed to help anyone who wants to develop his/her self. It consists of 13 different institutes and is currently provided to more than 300 free training courses in various fields. Aldarayn Academy differs from recent MOOCs; it still offers all courses by virtual classroom for the lecturer and students to communicate directly. At the same time, it records the lecture and then uploads it on the website and YouTube as well. The procedures in Aldarayn Academy is shown in Figure 1. 


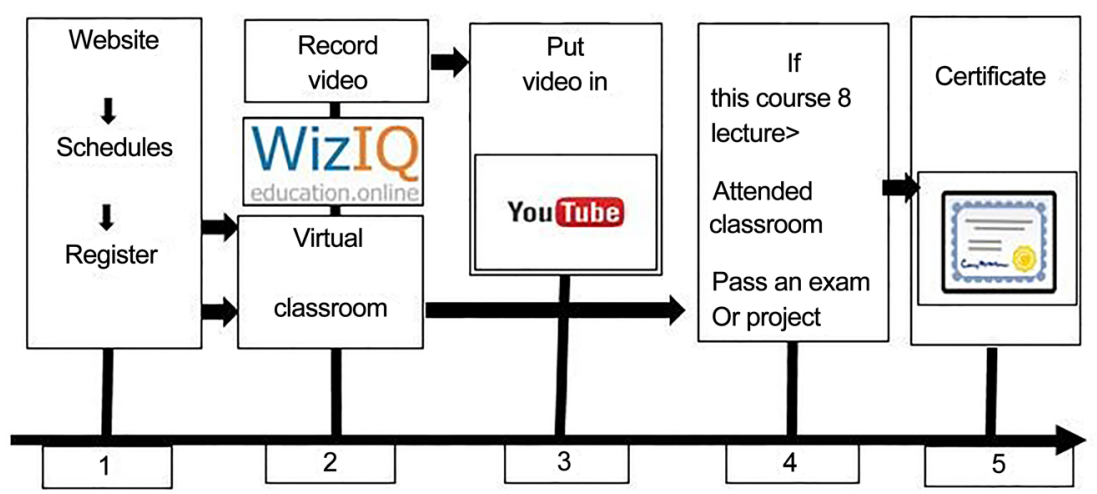

Figure 1. Procedures in Aldarayn Academy.

Aldarayn Academy gives certificates to those who complete the training course in accordance with certain conditions such as watching more than eight lectures in a course, passing the final exam or project, and attending most of the lectures on the virtual classroom. In Aldarayn Academy, all of the courses and lectures are based on volunteerism from the lecturers and the various teams.

\subsection{Arab ELearning Academy}

Arab ELearning Academy (AEA) is a social network for Arab academics and educational technology and training experts, and was established in August 2011 (Arab Elearning and Training Academy, 2014). The academy aspires to discuss and share each new concept related to educational technology. It is willing to share its experiences and knowledge with a variety of academics and trainers who are trying to develop teaching methods in their organizations and adopt various methods of modern technologies in order to provide a distinct academic education to their students.

Arab ELearning Academy offer online lectures, one lecture (one hour) is given every week in the areas related to education, educational technology and professional development for teachers. This academy uses Blackboard virtual classroom to provide lectures. Meanwhile, the lecture is recorded and placed in the academic channel in YouTube. The procedures in Arab ELearning Academy is shown in Figure 2.

Since 2011, Arab ELearning Academy (AEA) provided more than 190 lectures. AEA grants certificates in some lectures and sometimes it requires fees for issuing certificates.

\subsection{Tahrir Academy}

Tahrir Academy has been launched in February 2012 as a nonprofit educational platform that creates engaging learning experiences focusing on preparatory and secondary Egyptian curriculum to stimulate the minds of students (13 to 18 years old), empowering them to think, choose and decide (Tahrir Academy, 2014). Tahrir Academy has published more than 1000 short videos in the form of three main categories. These categories are: natural sciences and well-being, 
human sciences and languages, and mathematics and technology. In addition to experiments provided for pre-university students who were excluded from performing these experiments in their schools, all the offered courses cover areas like physics, astronomy, and Arabic grammar (Tarek, 2013). Tahrir Academy voluntarily offers free high quality lessons through its platform to increase the interactivity of students with their lessons. Its vision is to have the biggest video library that provides educational content in all fields for Egyptians (WSIS KCKnowledge Communities, 2015). The procedures in Tahrir Academy is shown in Figure 3.

On its official Facebook page, the Tahrir Academy announced to stop adding new content on the tenth of August 2015; a dilemma happened due to financial crises (Lutfy, 2015).

\section{Massive Open Online Courses (MOOCs) in Arab Countries}

After the year of 2102, which was named the year of MOOCs (Pappano, 2012), MOOCs phenomenon has spread dramatically around the world and the Arab countries were affected by this phenomenon. In 15, September 2013, the Saudi citizens named Fouad Al Farhan and Sami Al Hussayen launched Rwaq platform, a fully Arabic massive open online course (Brahimi \& Sarirete, 2015). It

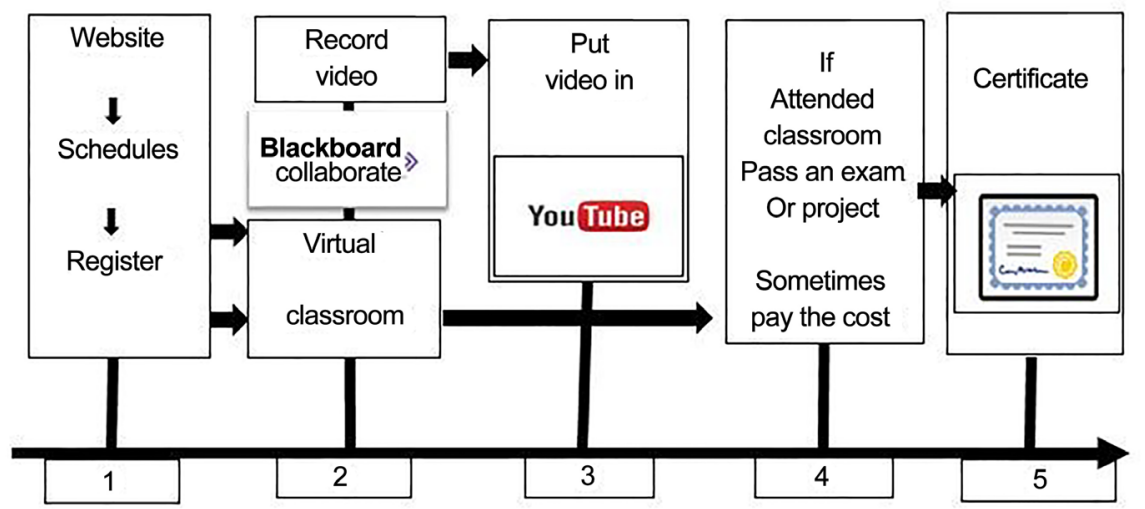

Figure 2. Procedures in Arab ELearning Academy.

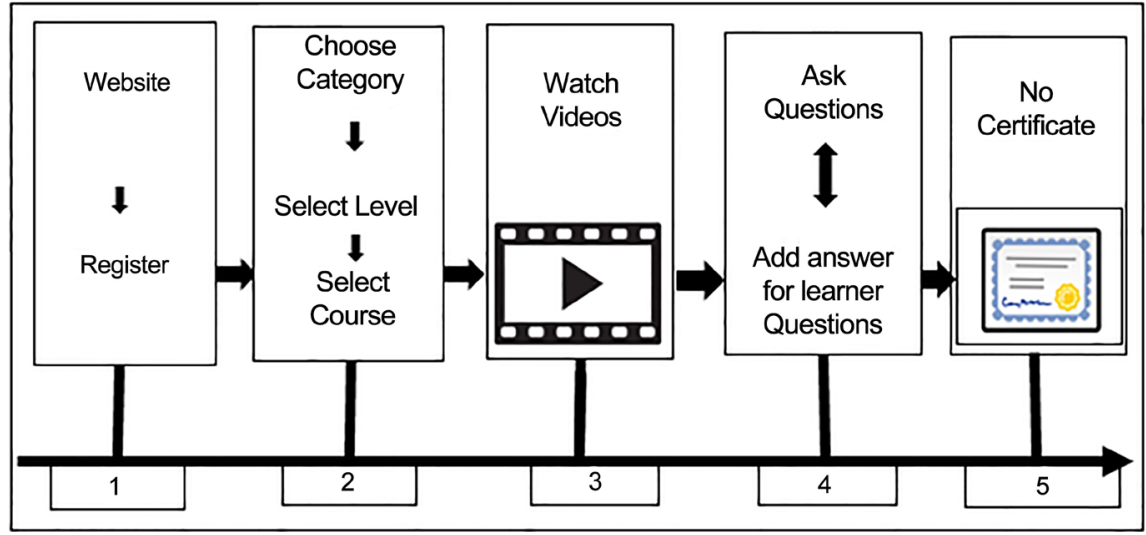

Figure 3. Procedures in Tahrir Academy. 
was the first platform providing MOOCs in Arab countries (Macleod, Haywood, Woodgate, \& Alkhatna, 2015).

In November 27, 2013, Dr. Ashraf Fagih presented his first MOOC course entitled: "How machines think: Introduction to computing techniques" in Rwaq Platform making him the first MOOC lecturer in the Arab world (Fagih, 2013). Eight months later, Edraak platform was launched as an initiative of the Queen Rania Foundation for Education and Development (QRF) Powered by the Open edX platform (edX, 2013). Since 2013 and until now, some initiatives of MOOCs in the Arab countries appeared, but did not spread like the recently mentioned platforms. In this part of paper, the Rwaq and Edraak platforms are represented as two cases of Arab MOOCs.

\subsection{Rwaq Platform}

Rwaq is a MOOCs platform providing free academic courses by Arab professors for Arabs in the Arabic language in various fields and disciplines, provided by academics distinguished from across the Arab countries. Until November 2015, the number of enrolments at the Rwaq platform reached about 330 thousand, among which 70 percent are males. Further, the proportion of 70 percent of enrolments is between the ages of 17 - 34 years. The enrolments resided in 172 countries around the world; approximately 40 percent of them are in Saudi Arabia. The top ten countries of residence of MOOC enrolments on Rwaq platform are shown in Figure 4.

From September 2013 until January 2016, Rwaq platform offered 91 courses within nine major categories. "Economics \& Management" has the highest value for "Courses Distribution at Rwaq". The percentage of categories compared to the total number of courses offered at Rwaq is shown in Figure 5.

Professors and teachers at Rwaq Platform belong to 13 Arab countries. The majority of professors and teachers are from Saudi Arabia: there is almost 45 percent of the total number of professors and teachers while only one member from countries like Morocco, Algeria, Iraq, Lebanon and Mauritania. This

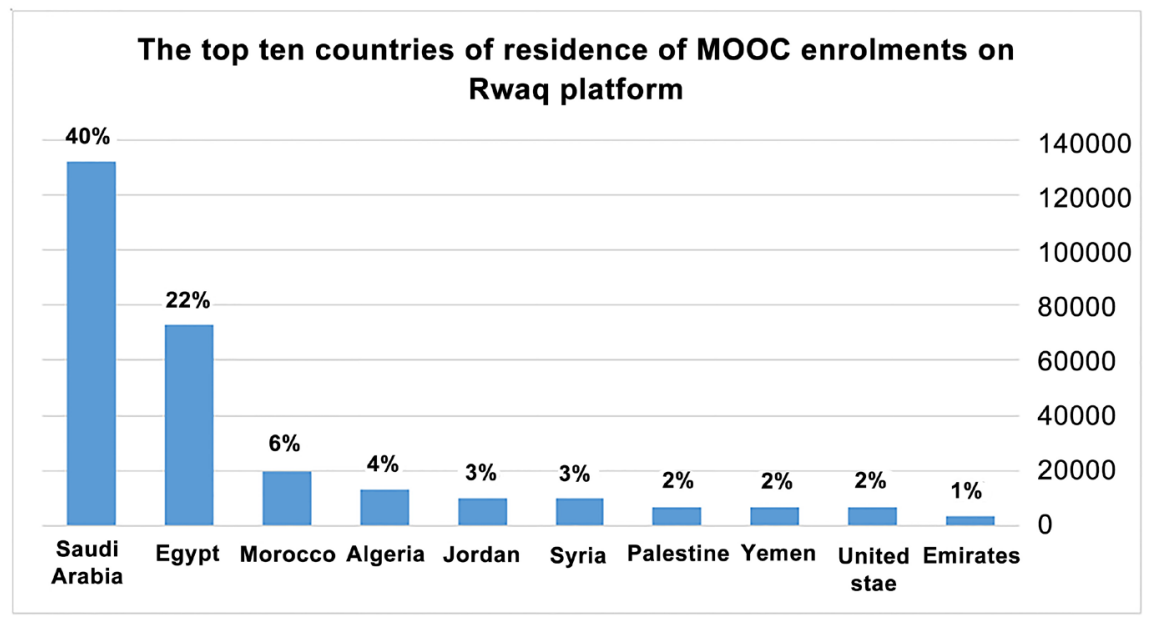

Figure 4. The top ten countries of residence of MOOC enrolments on Rwaq platform. 
means that many of professors in Arab universities are still far from participating in the Arab MOOC movement. The number of professors and teachers at Rwaq is shown in Figure 6.

Although it has been more than two years since the establishment of Rwaq platform, the Arab universities are still absent from the scene. Moreover, there are nine corporate partners with Rwaq platform, but no Arabian university is included yet.

\subsection{Edraak Platform}

Edraak is a non-profit massive open online courses (MOOCs) platform, initiated by the Queen Rania Foundation for Education and Development (QRF). This platform of Edraak was announced by edX and Queen Rania in 8, November 2013 (edX, 2013) and officially launched in May 19, 2014 (Hazlett, 2014). Edraak, with the logo "Knowledge is for those who seek it" has aimed to "revolutionize

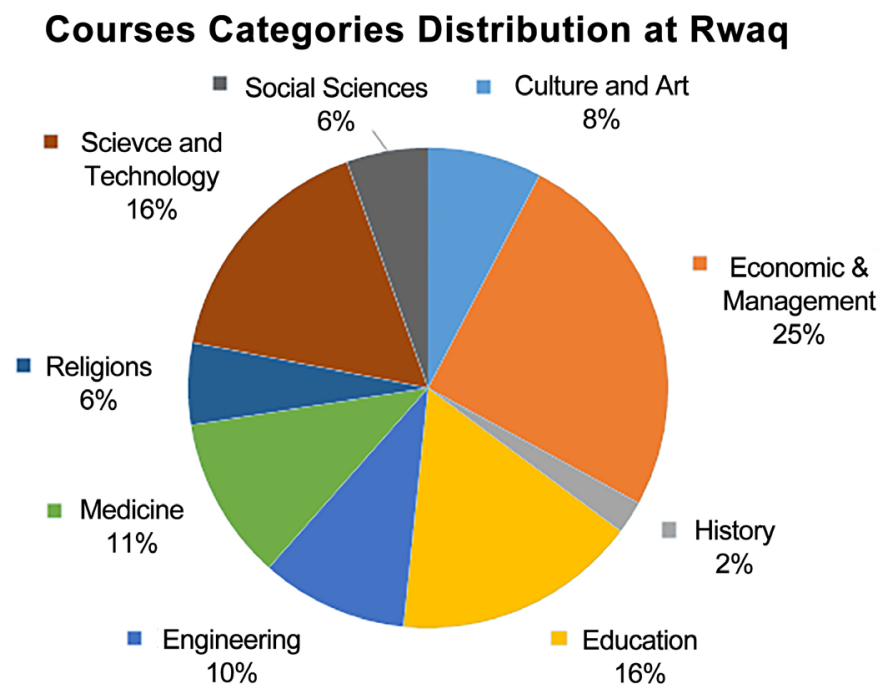

Figure 5. Distribution of courses offered by Rwaq.

\section{Countries of Professors and Teacher at Rwaq Platform}

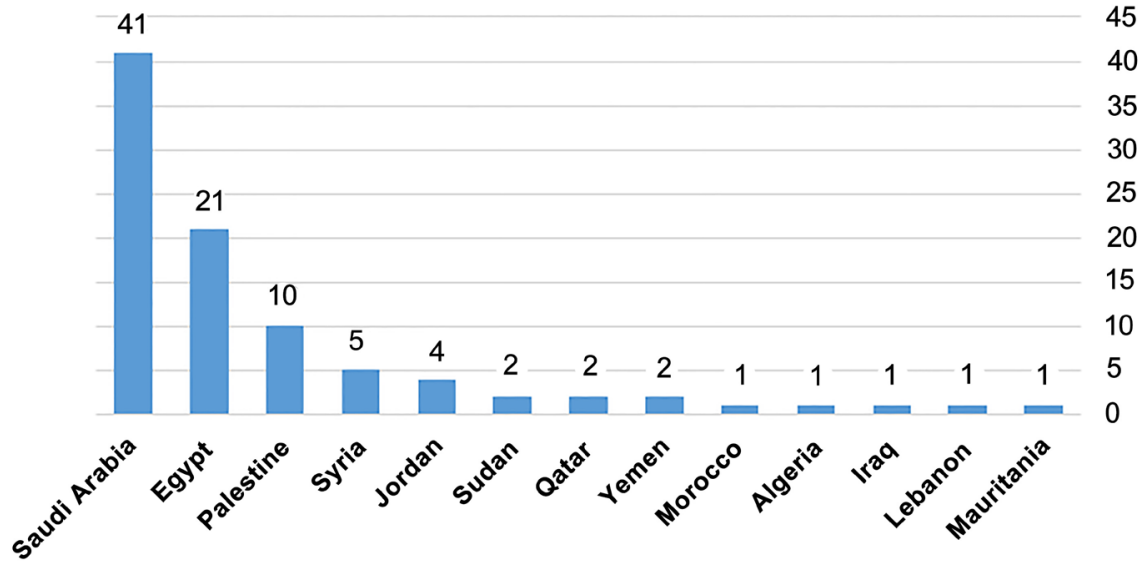

Figure 6. Countries of professors and teacher at Rwaq platform. 
the quality, nature and scale of education in the Arab World" (Vaidyula, Al-Khaledi, \& Al-Otaibi, 2015: p. 8). It also aims to spread lifelong education in the Arab countries through providing: 1) academic courses with excellent and original Arabic content given to Arabs by the best Arab professors and experts; 2) offering Arabic translations of select courses from top tier institutions like HarvardX, MITx, and UC BerkeleyX with edX partnership; 3) providing courses in English by university Arab professors and regional experts to non-Arabs around the world about the region and its history (JRTV Channel, 2014).

Though it has been over one and a half years since the establishment of Edraak platform, it has not yet offered any courses from Arab professors in English to non-Arabs around the world. The available courses in Edraak platform until (January 2016) are 29 courses, among which only six courses have been translated into Arabic from HarvardX, MITx, edX, and TU Delft. The courses within eleven major categories, "employment skills" category has the highest value of all courses distributed at Edraak for seven courses, then 'Health' six courses, "Business and Entrepreneurship" four courses, two courses for each of "STEM", "Arts \& Media", "Economics" and "Nature and Environment". Only one course is offered for each of "Education and Teaching", "Literature", "Architecture" and "Education for Citizenship".

Until early January 2016, the number of enrolments at the Edraak platform reached about 434 thousands, among which 64 percent are males. Eighty-three percent belong to nine Arab countries; more than 25 percent of them are from Egypt. The top ten countries in MOOC enrolments on Edraak platform are shown in Figure 7.

Edraak platform enrolments aged between 15 and 55 years old. Fifty-two percent of them hold a Bachelor's degree; while 21 percent have high school diplomas and 16 percent hold Master's degree. The distribution of enrolments age at Edraak platform is shown in Figure 8.

The number of enrollments in courses is ranging between 135,727 and 6133 students. The course "Learn English: Conversational Skills for Beginners" has the largest portion of enrollments, while the course "Healthcare Quality Management" has the least number of enrollments. Overall, among all courses offered in Edraak platform, the completion rate lies between $0.09 \%$ and $15.68 \%$. Courses whose percentage of completion rates more than ten percent are four courses "Child Mental Health" 15.68\%, "Nutrition and Health" 11.72\%, "Introduction to Human Resource Management" 10.62\%, and "Essential Career Development Skills" $10.45 \%$, all of these courses are produced in Arabic. While there are four other courses, the completion rate is less than $2 \%$. "Introduction to Solar Energy Part I" has 1.66\%; "Entrepreneurship 101 Who Is Your Customer?" course has $1.29 \%$. The course of "Intro to Computer Science and Programming" has 1.38\% and "Circuits and Electronics" course has 0.09\%. All of these courses are translated into Arabic, with three of them selected from MITx and the fourth one selected from edX. The reason behind this selection is that MITx and edX are related to scientific disciplines and difficult to comprehend easily. 


\section{Top ten countries of belong of MOOC enrolments on Edraak platform}

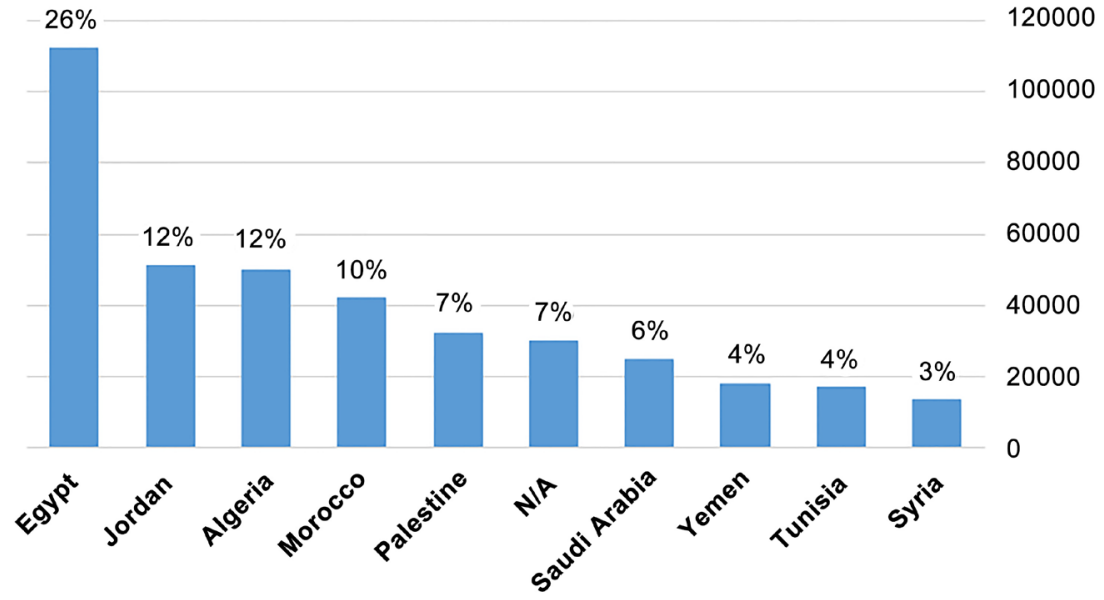

Figure 7. Top ten countries of belong of MOOC enrolments on Edraak platform.

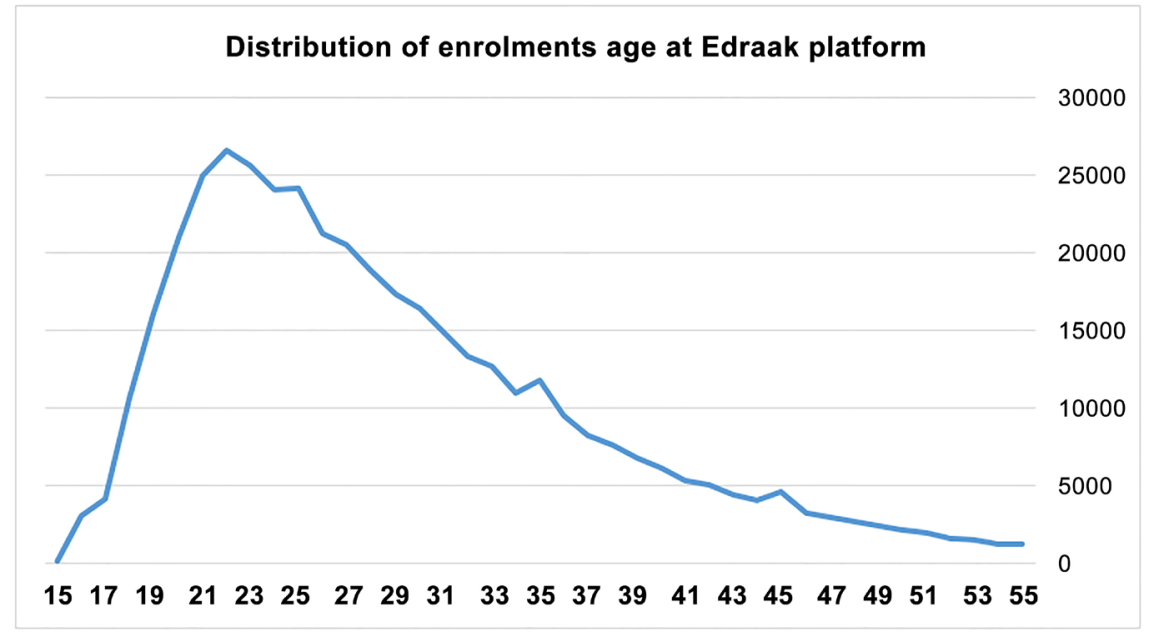

Figure 8. The Distribution of enrolments age at Edraak platform.

Therefore, the percentage of completion rate is getting lower and lower. Overall, the average completion rates for all courses is $5.57 \%$. This percentage is consistent with Jordan study (Jordan, 2014) that indicates the percentage of completion rates in MOOCs is less than $10 \%$ at the global level.

\section{Conclusion and Recommendations}

This paper reviewed some Arab initiatives in the Open Online Education that preceded the emergence of Massive Open Online Courses (MOOCs) in Arab countries, and highlighted two prominent initiatives named "Rwaq" and "Edraak". The results of this review indicate that most of the initiatives were individually driven, and have come from outside the Arab universities. The results also indicated that the participation of Arab universities is still very weak in the movement of Massive Open Online Courses (MOOCs).

It is also noted the MOOCs in the Arab world are still oriented to the Arabs. 
In other words, there are no courses oriented towards non-Arabs. The researcher recommends the involvement of Arab universities in the MOOCs movement in the Arab world, and the establishment of MOOCs platforms for the dissemination and teaching Arabic to non-Arabs.

\section{Acknowledgements}

The author would like to thank Sherif Halawa and Omar Al-Ithawi from Edraak platform, and Fouad Alfarhan from Rwaq platform for providing the data for this research.

\section{References}

Africa Internet Users (2015). Facebook and Population Statistics. Internetworldstats.com. http://www.internetworldstats.com/stats1.htm

Aldarayn Academy for Free Online Education (2014). Aldarayn.com. (In Arabic) http://www.aldarayn.com/mod/page/view.php?id=467

Arab Elearning and Training Academy-About Us (2014). Elearning-arab-academy.com. (In Arabic) http://arab-elearning-academy.com/about-us/arabic.html

Brahimi, T., \& Sarirete, A. (2015). Learning Outside the Classroom through MOOCs. Computers in Human Behavior, 51, 604-609.

Conole, G. G. (2015). MOOCs as Disruptive Technologies: Strategies for Enhancing the Learner Experience and Quality of MOOCs. Revista de Educación a Distancia, No. 39.

edX (2013). Queen Rania Foundation Partners with edX to Create First MOOC Portal for the Arab World. https://www.edx.org/press/queen-rania-foundation-partners-edx

Evans, C., \& Schenarts, K. (2016). Evolving Educational Techniques in Surgical Training. Surgical Clinics of North America, 96, 71-88. https://doi.org/10.1016/j.suc.2015.09.005

Fagih, A. (2013). How Machines Think: Introduction to Computing Techniques. Rwaq.org. (In Arabic) https://www.rwaq.org/courses/how-machines-think

Hazlett, C. (2014). Queen Rania Foundation Launches Edraak, a MOOC Portal for the Arab World. http://blog.edx.org/queen-rania-foundation-launches-edraak

Jansen, D., Schuwer, R., Teixeira, A., \& Aydin, C. H. (2015). Comparing MOOC Adoption Strategies in Europe: Results from the HOME Project Survey. The International Review of Research in Open and Distributed Learning, 16. https://doi.org/10.19173/irrodl.v16i6.2154

Jordan, K. (2014). Initial Trends in Enrolment and Completion of Massive Open Online Courses. The International Review of Research in Open and Distributed Learning, 15. https://doi.org/10.19173/irrodl.v15i1.1651

JRTV Channel (2014). N. Dakkak, Interviewee, Interview with Director of Edraak initiative Nafez Dakkak. YouTube Video. (In Arabic) https://www.youtube.com/watch?v=BHsanTV88EQ

Lutfy, S. (2015). Tahrir Academy: The Most Outstanding Arab Educational Experience. Arageek. (In Arabic) http://www.arageek.com/edu/2015/08/12/thariracademy.html

Macleod, H., Haywood, J., Woodgate, A., \& Alkhatnai, M. (2015). Emerging Patterns in MOOCs: Learners, Course Designs and Directions. TechTrends, 59, 56-63. https://doi.org/10.1007/s11528-014-0821-y

Middle East Internet Statistics (2015). Population, Facebook and Telecommunications Reports. Internetworldstats.com. http://www.internetworldstats.com/stats5.htm 
Pappano, L. (2012). The Year of the MOOC. The New York Times, 2(12), 2012.

Tahrir Academy-About Us (2014). Tahrir Academy. http://tahriracademy.org/about-us-en

Tarek, R. (2013). Tahrir Academy Looks to Revolutionize Education in Egypt. Wamda.com.

http://www.wamda.com/2013/04/tahrir-academy-looks-to-revolutionize-education-inegypt

Vaidyula, S., Al-Khaledi, S., \& Al-Otaibi, M. (2015). It is High Time for Oil \& Gas Companies to Delve into the World of MOOCs. SPE Kuwait Oil and Gas Show and Conference, Mishref, Kuwait, 11-14 October. https://doi.org/10.2118/175347-MS

WSIS KC-Knowledge Communities (2015) Wsis-community.org. http://www.wsis-community.org/pg/directory/display/1438624

Zhang, W., Wang, R., \& Chen, J. (2015). Flipped Classroom Model Based Instruction of College English in ICT Environment. International Conference on Arts, Design and Contemporary Education (ICADCE 2015), 810-814.

https://doi.org/10.2991/icadce-15.2015.196

Submit or recommend next manuscript to SCIRP and we will provide best service for you:

Accepting pre-submission inquiries through Email, Facebook, LinkedIn, Twitter, etc. A wide selection of journals (inclusive of 9 subjects, more than 200 journals)

Providing 24-hour high-quality service

User-friendly online submission system

Fair and swift peer-review system

Efficient typesetting and proofreading procedure

Display of the result of downloads and visits, as well as the number of cited articles

Maximum dissemination of your research work

Submit your manuscript at: http://papersubmission.scirp.org/

Or contact ce@scirp.org 